\title{
REGIONAL ECONOMY IN THE CONDITIONS OF DECENTRALIZED GOVERNANCE: INSTITUTIONAL ASPECT
}

Ольга Попело

\section{РЕГІОНАЛЬНА ЕКОНОМІКА В УМОВАХ ДЕЦЕНТРАЛІЗОВАНОГО УПРАВЛІННЯ: ІНСТИТУЦІОНАЛЬНИЙ АСПЕКТ}

Ольга Попело

\section{РЕГИОНАЛЬНАЯ ЭКОНОМИКА В УСЛОВИЯХ ДЕЦЕНТРАЛИЗОВАННОГО УПРАВЛЕНИЯ: ИНСТИТУЦИОНАЛЬНЫЙ АСПЕКТ}

The article examines the institutional core of the regional economy in terms of decentralized management and strengthening competitiveness. The main approaches to the decentralization of economic management on the basis of localization are outlined. The factors of formation of effective territorial communities are analyzed. Reconstructive and modernization aspects of the formation of a new institutional core are proposed. The author's interpretation of the concept of harmonization of institutional influence on the processes of regional development is given.

Keywords: regional economy; region; decentralized management; institutional core; competitiveness.

Fig.: 1. References: 12.

У статті досліджено інституціональне ядро функиіонування регіональної економіки в умовах децентралізованого управління та посилення конкурентоспроможності. Окреслено основні підходи до дещентралізації управління економікою на засадах локалізації. Проаналізовано чинники формування ефективних територіальних громад. Запропоновано реконструктивно-модернізаційні аспекти становлення нового інституціонального ядра. Надано авторське тлумачення поняття гармонізації інституціонального впливу на процеси регіонального розвитку.

Ключові слова: регіональна економіка; регіон, децентралізоване управління; інституціональне ядро; конкурентоспроможність.

Рис.: 1. Бібл.: 12.

В статье исследованы институииональное ядро функиионирования региональной экономики в условиях деиентрализованного управления и усиления конкурентоспособности. Определены основные подходы к децентрализации управления экономикой на основе локализачии. Проанализированы факторы формирования эффективных территориальных общин. Предложено реконструктивно-модернизационные аспекты становления нового институционального ядра. Предоставлено авторское толкование понятия гармонизачии институционального влияния на процессы регионального развития.

Ключевые слова: региональная экономика; регион; децентрализованное управление; институциональное ядро; конкурентоспособность.

Рис.: 1. Библ.: 12.

JEL Classification: R500; R580

Problem statement. Under the conditions of strengthening of globalization processes in world economic systems a regional aspect of competition is important. At the regional level, it constantly contributes to a higher level of satisfaction of various needs in goods and services, encourages commodity producers to develop markets at different hierarchical levels (community - region - state - global world) and search ways to modernize the production, improving quality while reducing costs and prices for products. In this way, competition is an element that organizes competitions for markets between regions, countries and even their associations, it contributes to the establishment of regional specialization, qualitative improvement of the state of productive forces.

Analysis of recent research hand publications. Many scientific works of domestic and foreign scientists are devoted to problems of institutional aspects of the functioning of the regional economy, among which O. Amosha, M. Butko [1; 2], A. Chukhno, B. Danylyshyn, V. Dubnytskyi [5], S. Fedulova, Z. Gerasymchuk, V. Heyets, V. Kulishov [7], I. Lukinov, V. Marhasova [6], O. Padalka [7], V. Symonenko [11], V. Tarasevych [10], P. Yeshchenko [9] etc.

Selection of previously unsettled parts of the general problem. The analysis of the results of scientific works shows the importance of the question of institutional aspects of the functioning of the regional economy in the context of decentralization and taking into account the processes of strengthening competitiveness, but in the current conditions of state formation, these issues need further research and analysis.

(c) Попело О. В., 2020 
ПРОБЛЕМИ МЕНЕДЖМЕНТУ ТА РОЗВИТКУ ПРОДУКТИВНИХ СИЛ РЕГІОНУ

The purpose of the article is to study the institutional core of the regional economy in the conditions of decentralized management.

Statement material. The global competition strategy of Ukraine should provide for the predominance and retention of a decent place in the geo-economic competitive environment. At the heart of its formation purposeful policy of the state should underlie, the support of microeconomic subjects should be its basis. The success of the latter in the global competitive competition is able to ensure success of the country's competitive strategy. The initial point of its formation is to identify factors that could either contribute to the successful positioning of the country in a global competitive environment, or slow it down.

Based on the existing scientific genesis, the modern regional competitiveness can be characterized as spatial capacity in the conditions of increased globalization trends to ensure effective use of existing and implementation of unique resources of spatial, mineral-raw, industrial, scientific and technical, intellectual, infrastructure and cultural-ethnic direction to accelerate the modernization of productive forces, increase living standards and consolidate the longterm competitive advantage.

It is stressed that the priority task of our state to the nearest prospect is to ensure implementation of the policy aimed at creating such a level of competitiveness of the national economy which would allow in the conditions of the new character of the transformations of globalized economic processes to be a worthy entity in the international economic relations, capable, in contrast to corporate interests, which often have a globalizing character, to protect national interests, comprehensively focusing on the policy of avoiding threatening debt [8].

One of the ways of creating and maintaining competitive advantage is taking into account the overall development strategy of the country's historical, geographical, socio-economic and environmental features of the regions which can seriously influence success in competition. The need to consolidate the Ukrainian positions in international division of labor determines the objective need for decentralization of social development [1].

P. Yeshchenko o focuses on the fact that when developing economic policy aimed at restoring and raising the economy of Ukraine, it is necessary to take into account the theoretical provision that the great duration of the crisis and depression is more destructive to the fate of further economic growth than the depth of the recession. In the case of deep but low-term recession it is easier to maintain production and creative groups because the qualification of employees and high-performance skills [9] are not lost.

According to V. Tarasevych, imperative for a successful future country national harmony can be achieved not so much in the social halls and high offices, as in the process of daily economic, social and political activities of millions of citizens, in the process of active interaction of their dissimilar interests, including economic ones. Without such a full interaction, it is difficult to rely on creation, dominance and effective implementation of national interests and goals - not only common for all social clusters (groups, strata) and citizens who form them, but also synergistic ones [10].

Taking into account the decentralization problem established in Ukraine, its combination with the creation of adequate conditions of regional and local development becomes of particular relevance because decentralization as a way to increase the capacity of local selfgovernment to influence the development of territories has never been perceived in postsoviet Ukraine as a serious factor in overall development. It is always the opposed attempt, based solely on political motives, to allocate authoritative powers in favor of the center for the concentration of financial resources with their further "distribution" on the basis of a formula or without it. In this respect, decentralization of local governments was considered as a way to gain more authority and financial resources for them.

S. Romaniuk points out that due to the institutional weakness of the Ukrainian state in modern conditions, implementation of the rapid radical full-scale decentralization is an extremely difficult task. It should be borne in mind that the development of any territory (country, region, 
community) is always deterministic in time and space. Each of these areas has an excellent history, legacy, political problems, and other characteristics that affect the determination of the trajectory of economic growth, social prospects, etc. The size of an individual country, the level of development (political, economic, cultural, etc.) of other countries surrounding it also has a significant impact on the development. Such variability determines the circumstances and peculiarities that change all the time between countries and within countries. It defines the character, way, directions of reforms and their speed. The transformation model that has been successfully implemented in a specific time period in a certain country is unique, and expectations for its repetition with similar results under other circumstances in another time period in another country are groundless. Decentralization should be aimed at strengthening the capacity of the state and community to the conditions of economic and social development that have been formed in Ukraine. The most optimum ratio of centralization - decentralization, the use of different types and forms is the most acceptable in the current conditions.

According to $\mathrm{V}$. Zahorskyi, the modelling of the national economy needs changes of management mechanisms in accordance with the transformation of the structure of productive forces and production relations. In today's conditions of functioning of the Ukrainian economy, the primary problem arises in overcoming regional differences affecting the establishment of mechanisms for effective interaction of the centre with regional and local government bodies [12].

The policy of decentralization, declared at all levels of state power now, causes fundamental changes in the principles and philosophy of public administration of regional economic systems aimed at democratization of management, powers and increased responsibilities. In the future it is advisable to investigate the influence of specific regions in forming the general system of public administration of economic processes [12].

Implementation of the decentralization reform in Ukraine singles out two main pillars of its bearing poles: the state and territorial communities. The reform increases the opportunities of local self-government, especially newly formed communities and simultaneously has to change the old organization of power and lay a new national basis for the modern corps of public servants and officials of local government. In fact, they are supervised as for their observance of the Constitution and the laws of Ukraine, execution of state programs, and they will organize and guide the interaction of local bodies with central ones, especially in the state of martial law or emergency, hazardous environmental situations, etc. They will create a new framework of public relations; become actors of the institutional market, generators of modern functional communication systems, at the same time tools of the innovative way to manage the country under the influence of European integration.

At the current stage of the state building, public administration reform was proclaimed as one of the key reforms, in particular, among 10 reforms for priority implementation in the strategy for sustainable development "Ukraine-2020" approved by decree the of President of Ukraine. The coalition agreement among the main areas of decentralization and local selfgovernment reform defines the formation of self-sufficient communities as the administrativeterritorial units of the basic level. Reform of administrative and territorial structure is provided by the new State strategy for regional development up to 2020 adopted in August 2014 [8].

The lack of an effective regional policy and the organizational and economic mechanism for sustainable development of regions, the presence of depressed regions and the problems of structural transformations in the old industrial regions resulted in a rather radical differentiation of the Ukrainian regions by the level of economic and social development [2].

T. Lazareva notes that the increase in interregional asymmetry is accompanied by an increase in the number of depressed, problematic and backward areas. Under such conditions, the territory of Ukraine cannot be considered a homogeneous and balanced economic space [5]. 
ПРОБЛЕМИ МЕНЕДЖМЕНТУ ТА РОЗВИТКУ ПРОДУКТИВНИХ СИЛ РЕГІОНУ

According to O. Vlasiuk, increase of the powers of communities in their relations with the center, the right to form and implement strategies for development and to determine the prospects of the region without excessive administrative interference with Kyiv, concentration necessary for the self-development of financial resources at the level of territorial communities were and remain the main demands on the ground. Decentralization in this regard is not an unconditional panacea, but it is quite able to satisfy the "appetites" of regions with respect to self-development and preserve the uniformity and integrity of the state.

O. Padalka and V. Kulishev argue that the decentralization policy should be aimed at creating conditions for increasing the competitiveness of the regions as a basis of dynamic development of the state. In this connection it is necessary to redirect the economy of regions to an innovative model of development. The main strategic resources and the main factors of economic growth in the regions are the structural changes, processes, reforms and human potential, in which regions are quite able to regulate the existing potential, which as a result will maximize the contribution to national economy, ensure the increasing of competitive advantage on the regional, national and world markets [7].

The process of decentralization of power and reforming of local self-government foresees the creation of an effective state governance system of regional development capable of providing high quality and accessible public services for the population guaranteeing the safety of human activity regardless of their place of residence. Decentralization envisages granting to local authorities the maximum number of powers on the basis of subsidiarity, sufficient level of resource provision (in particular, financial resources) which will be a strong basis of sustainable development promoting the growth of the responsibility for fulfilling their commitments to the development of the community and enforcing the legality. Decentralization is the only way to build a strong, unitary, democratic, European Ukraine. The integral part of decentralization is strengthening of the accountability of authorities to the places of voters residents of the community, citizens, for whose welfare all the branches of state power in Ukraine should work.

The recent economic model, focused on reconstruction of the national economy through decentralization and empowerment of communities, should fundamentally change the role of state nature management bodies - the Ministry of Ecology and Resources of Ukraine, state agencies for management of relevant natural resources (state geocadastre, state forestry, state agency, etc.). Thus, more accounting, supervisory boards and regulatory functions are fixed for them and territorial communities in the decentralization process, devolution and delegation of powers may transfer a significant part of the rights of the permissive, prescription and control of nature (from the organizations). It is also possible to significantly reduce the specific weight of natural resources of the national importance in the natural wealth of the country, passing them in the use and disposal of territorial communities.

The main approaches to the decentralization of economic management based on the localization include the following fundamental factors:

- firstly, the transfer of part of the managerial financial and production powers from the center to the region;

- secondly, the territorial community assumes the functions of mobilizing funds to summarize the balance of income with costs;

- -thirdly, the mobilization of investments in the priority areas of the economy to optimize the proportions of the production, income and consumption;

- fourthly, the economic freedom to organize entrepreneurship to increase the number of new high-performance jobs and to create their own product for domestic consumption and export;

- fifthly, the dominance of private property and private initiative in the organization of the production of goods and services and their implementation within the private-state partnership; 
- sixthly, increasing the competitive advantages and their actions in the domestic and foreign markets;

- seventhly, the increase in productivity, the mass of invested capital and production efficiency.

An important problem of transition countries is to reduce the excessive centralization in decision-making and administration to ensure effective localization of resources to provide public goods and motivation for their provision at the expense of the minimum costs. Achievement of such structural changes in the economy is a very difficult task since there are a number of institutional conditions and problems accompanying the decentralization processes in these countries and making it even more difficult. Therefore, in implementing the decentralization reform we should not expect rapid results of improvement of the development management quality on the ground. The experience of such reforms in transit countries proved the importance of adequate institutional arrangement of the country's economic space which could lead to a positive impact of decentralization in economic development only in medium- or long-term. In general, foreign experience mainly confirms the impact of fiscal processes.

However, even after the unification, most of the territorial communities are unlikely to be financially self-sufficient. The planned average size of Ukrainian rural communities is at the level of 9. Residents, even in such high-income countries as Finland has not given the opportunity to perform a wide range of functions. Foreign practice shows that the optimum performance of health functions is possible in a community, which covers more than 20 thousand and education - more than 50 thousand people. This means that even amalgamated communities need an additional toolkit for combining efforts with other communities to perform a number of functions.

S. Romaniuk draws attention to the fact that the important threat of decentralization in Ukraine is a possibility of reducing the volume of revenues from the PIT as a result of the tax reform. In most EU member states, this source of income is the main one for local budgets, and it is unlikely to compensate for its reduction by other sources of tax. With all the importance of property taxes, it is not necessary to overestimate their value for local budgets: even in high-capitalization countries, such sources mostly do not exceed $10 \%$ of local budget revenues. Therefore, when choosing a draft tax reform it is necessary to take into account the importance of PIT revenues for local budgets [8].

The practical implementation of decentralization reforms brings Ukraine closer to European development standards, since the implementation of the decentralization principle and increasing the effectiveness of local self-government are considered as the basis for effective policy in the EU countries and other developed countries of the world. Ukraine won the right to join the community of democracies and recognizes that the full implementation of the association agreement with the EU requires the implementation of comprehensive reforms, among them there is optimization of relations between the center and the regions and development of one of the leading places to the utmost. We should start out from understanding that the reform is necessary, regardless of the duration of the European integration process. Effective decentralization is the state attribute with which Ukraine can occupy a decent place within the European Community.

Awareness of the degree of influence of the unitary state on regional development, and also taking into account the challenges caused by increased European integration processes do not doubt the necessity of reviewing traditional approaches to engagement potential of territorial communities, despite the fact that the bifurcation point of the state core of Ukraine is in the red.

M. Butko argues that decentralization, coupled with the concentration of power of authority is really the only way to use completely the territorial potential of Ukraine, which has found an effective landing for most European Countries, including Poland, the Czech Republic, Hungary, Slovakia and others, which, together with our state, are raging the path of deep social transformations, but have diametrically opposed deliverables [2]. 
ПРОБЛЕМИ МЕНЕДЖМЕНТУ ТА РОЗВИТКУ ПРОДУКТИВНИХ СИЛ РЕГІОНУ

Thus, decentralization is a kind of imperative of time, but the implementation of this course contains a number of problems, challenges and even threats to be taken into account during the implementation of the road map of its realization into the institutional body of the state, strategy of the productive forces modernization and practice of public authorities management, especially at a basic level.

These etymological conditions outline the decentralization entity only through the prism of higher budget self-sufficiency of territorial communities without taking into account the motivation, needs, values, interests, creative activity of a person, its incentives for innovation activity, permanent search of new knowledge, harmonization of relations with surrounding natural environment is the illusion of effectiveness of the public authorities' activity at both the central and local levels.

In view of these circumstances, the decentralization strategy, in our opinion, should be based on the deep foundations of institutionalism, manifested on the one hand, in strengthening the foundations of the unitarily of our state, and on the other - the factor of human engagement as a dominant functioning of territorial communities, their cohesion, competence and focus on solving inherited and accumulated problems in the transformational period. After all, the reform is proclaimed in the context of social development of a person, preservation of the identity of the nation, historical heritage, skills and intellectual potential, it should harmonize economic, fiscal, social humanitarian decentralization with the needs of national defense, strengthening of the state's borders and European integration processes [2].

A comprehensive interpretation of decentralization involves combination of such elements:

- economic independence of communities through the work of the existing potential and creation of new jobs;

- budget decentralization (in particular, due to the adoption of changes to the budget and tax codes of Ukraine) to transfer necessary resources (especially financial ones) to the local level for the realization of powers transferred from the center to the regions;

- change of administrative and territorial structure of the country (primarily by means of optimizing the size of community, introducing effective incentives for voluntary amalgamation of communities) with the purpose to approach public services to their direct consumermember territorial community;

- responsibility in the field of rational nature conservation and environment for future generations;

- optimal distribution of powers at the level of "community- region" (both vertically and horizontally) which forms the basis for community self-development.

The basic idea of decentralization is that in the process of expanding the powers of local authorities and obtaining appropriate resource security, territorial communities should be considered as key "stakeholders" for reforming the regional landscape. Community's interest in replenishment of local budgets, provision of economic growth at the local level and selfdevelopment, creation of all residents of safe and comfortable living conditions requires innovative solutions, among them: stimulation of territorial communities to a voluntary association (which will undoubtedly positively affect the strengthening of their financial and resource capacity). In addition, the voluntary amalgamation of communities will allow approximating the provision of public services to the direct consumer - to the ordinary emirates of the community.

$\mathrm{V}$. Symonenko stresses that instead of analyzing previous unsuccessful attempts to make relevant conclusions, to develop a clear strategy for implementing reforms, to put specific intermediate and final goals, the government of the country started everything with a clean slate. Floating in the thin layer of problems, without immersion into their depth, instead of a thorough and principled change of the system of state and local administration, creation of effective subjects of management at all levels, - the government went through simple delega- 
tion of powers and redistribution of financial resources to the level of local self-government without any calculations on the possibility of their execution. Nobody wants to or is able to understand that decentralization is not a mere redistribution of powers and financial resources - it is not a transformation of 11000 local councils in 1500-2000 communities, this is primarily the construction of a new, effective control at all levels [9].

The methodology for the substantiation of the decentralization model implies taking into account that it is extremely important to understand the existence of interconnection and interaction between such institutions as amalgamation of the state and the territorial community to form the conditions of development of the country. The state and community always act as complementary forms of organization of society.

Creation of a competitive environment, introducing standards of efficiency and justice common to society, possible only at the national level, should restrict the privileges of such groups and counteract them through redistributive mechanisms. Acceptable interaction between the state and the community allows obtaining a potentially positive effect for each of these institutes to delimit powers, responsibility and autonomy in certain spheres (subsidiarity of tasks) in accordance with the assigned tasks of development of obligation. These are the tasks related to the creation of conditions for economic development, the increase of citizens' welfare, and the principles according to which decentralization should be made. The powers cannot be detached from the task and related responsibility of different territorial levels of central authority and local government for their implementation. Usually these tasks are primarily associated with the provision of public services to the population. With the exception of a very limited range of services with insignificant or absent-scale economies, such as garbage disposal, the central government will always be involved in providing them even after radical decentralization (a problem with the removal of garbage led to the tragedy in Lviv, certifying that even in the organization of providing such a service local authorities needed the interference of central authorities).

The formation of effective territorial communities requires the consideration of dozens, if not hundreds, of various factors of different groups - economic, social, natural, demographic, historical, mental, national, infrastructure, etc.. It is impossible to do this with an equally high degree of sufficiency. At the same time it is necessary to consider the following factors:

- economic. The economic environment largely determines the financial self-sufficiency of communities and, therefore, the possibility of providing residents with the necessary services. The level of economic development of local communities will have greater impact on their self-sufficiency because of the budget. Therefore, when modelling administrativeterritorial units, it is important to identify areas and centers of existing or potential economic activity. They should be considered as main bodies of the united economically self-sufficient territorial communities;

- infrastructural. Provision of administrative, social, cultural, communal and other services to the necessary groups populations requires appropriate infrastructure facilities. Their presence and accommodation are considered as one of the decisive factors in determining the structure of the territorial communities, their administrative centers;

- administrative and managerial. Availability of population and quality of administrative services is one of the main requirements that must be observed in the process of administrative-territorial reform. This requires special attention to the determination of the centers of providing such services and the availability of trained specialists;

- natural-geographical. In many cases, they have a decisive influence on transportation accessibility to the centers of providing the necessary public services and communication possibilities within the territorial communities. Mountain ranges, rivers, marsh and woodlands are the natural boundaries that divide the territorial community; 
ПРОБЛЕМИ МЕНЕДЖМЕНТУ ТА РОЗВИТКУ ПРОДУКТИВНИХ СИЛ РЕГІОНУ

- sociomodographic. Strength, sex and age composition of population changes dynamics, migration streams, including local labor-intensive, requires analysis and consideration in modelling;

- ethno-cultural. It is also important to consider experience of local community selfgovernment, historical experience, performance of administrative centers settlements in the past, ethno-cultural peculiarities when modelling communities.

One of the tasks before the local government reform was to reach the high level of financial capacity by territorial communities in addressing the issues of local significance. The essence of the reform was to transform the public administration mechanism through the redistribution of powers between state bodies and local governments in order to transform the selfgovernment into a real instrument of effective progressive development of communities. The territorial community is the end user of many administrative services and most of the public goods of the state, and therefore, at the level of communities a proper level of socio-economic welfare should be created.

The activities of amalgamated communities would be advisable to start not from the expected growth of the local budget revenues by securing a part of all state taxes and fees, which, incidentally, does not lead to the growth of national budget as a whole, but to form sustainable development strategies of the corresponding territory, it should become a motivation for creating new, competitive workplaces.

The starting point for this regional development strategy would be to focus the activity of the territorial community on the formation of potentially productive territory for attracting investments and introducing innovations, accelerated development of industrial production with a high rate of added value, renewal of production capacities and production infrastructure, implementation of measures to counteract environmental pollution and depletion of natural resources [2].

Decentralization creates opportunities for effective operation of the management system at the local level and improving the quality of public services, but it also bears certain threats related to the increased asymmetry of the development of communities when "wealthy communities" become richer and the poor ones become poorer. At the intra-regional level, the differentiation in terms of own income budgets reaches tens, and for revenues from some taxes - hundreds of times in the calculation for 1 resident. The self-elimination of state and regional authorities from settlement of these problems may lead to the dissemination of the economic depression when many communities fail to fulfil their functions and each year more and more budgetary funds will be necessary for basic needs coverage. Among the areas of leveling the risks of strengthening the intra-regional differentiation in the development of communities are [8]:

- increasing role of regional level of management and concretization of its functions in the context of decentralization;

- empowering the regional level of management of the financial resources that will support the implementation of economic development projects in the region;

- transfer of financial resources on the basic level that the community can direct to its own economic development, not only for repair or development of social infrastructure or its maintenance;

- dissemination of impulses from cities to the surrounding areas;

- revision of budget alignment mechanisms;

- transformation into a real instrument of implementation of regional policy with the maximum elimination of the political and corrupt component in allocation of funds.

In the existing system of local self-government of Ukraine there are other problems that significantly affect the efficiency and capacity of communities: 
- strategic planning actions for rural development are impossible without involvement of significant human and financial resources, which, in turn, require appropriate resource (financial, personnel) base, virtually non-existent, from territorial communities;

- in almost every region there are settlements located on the territory of one district, but administratively annexed to another. As a consequence, at least in the plan of infrastructure provision citizens become hostages of unsuccessful administrative-territorial demarcation;

- cities of oblast and rayon significance are often "sandwiched" between suburban villages, it objectively prevents the development of both ones, aggravates the conflict situations in the process of resolving the "land issues";

- many local problems throughout the territory of the state can be effectively resolved at the place of their occurrence, but as a result of an imperfect model of relations between the center and periphery, members of communities are often deprived of operational influence on the development of their settlements;

- over $90 \%$ of budgets of communities are subsidized, and the budget area of local authorities is ensured only by $3 / 4$ from real needs; there is chronic underfunding from the state budget for target programs (support of socio-economic development of towns, development of municipal electric transport, provision of drinking water, reforming and development of housing and communal services, etc.). To improve the living conditions of a person on the ground the introduction of cardinal managerial decisions on the search for domestic development resources at the local level is required on the ground [2].

In addition, from the nationwide position decentralization of authoritative powers should also not trigger the manifestation of centrifugal processes, which, in conditions of political instability, social tensions and military aggression by Russia will help to weaken statehood. In the center of decentralization the person must become a human being, because it is for the sake of its development. At this, resources are the base where people are special national resource, and their activities, in particular innovative, are an engine for converting resources into potential, and potential in capital.

As for the new trends, it should also be noted that regionalization is also global in the context of its proliferation and its effects on sustainable development processes. This phenomenon characterizes the essence of "new regionalism, i.e. automation, which occurs against the background of integration processes, is their counterweight and certain guarantor of sustainable development of the entire communication system" [5].

Thus, the complex nature of regional policy, collision or interaction of interests of different spheres of society in the background of the region, regional inertia for changes require a balanced scientific support, comprehensive justification of decisions of regional development. Mistakes in the choice of regional strategy, structure of its economy, methods of resource use will be due to society. The population of the region is much more expensive than mistakes in the selection of industrial technologies, sectorial organization of production. On the one hand, decentralization of management, strengthening of territorial aspects of development, the regional specificity of integration processes of the country become effective within the national development strategy. On the other hand, these trends caused identification of a specific regional consciousness enabling provision of a national strategy for the development of appropriate regional fullness, and sometimes corrective influences, by which changes both at regional and national levels will acquire irreversible, natural and directional features [5].

New regionalism calls for the implementation of the parity balance of the centralization and regional decentralization of power, that is, the transfer of objects of departure and responsibility from a sedentary "center" to more mobile and locally oriented regional structures. It is clear that such advantages may be realized if the decentralized regional authorities possess the appropriate administrative, financial and material resources. 
ПРОБЛЕМИ МЕНЕДЖМЕНТУ ТА РОЗВИТКУ ПРОДУКТИВНИХ СИЛ РЕГІОНУ

Supporters of the theory of "new regionalism" believe that regional development should be based primarily on domestic potential - local economy and advantages of cross-sectorial production with the transmission of a significant part of power authority to regional authorities. The basic principle of "new" regionalism is the expansion of functions and powers at the regional level with simultaneous increase of liability to the public and the state; overcoming the institutional, socio-economic and moral-psychological obstacles to the development of regions is an urgent requirement of time now; the search for an optimum balance between decentralization of management and "sole authorities" is particularly relevant now in the context of political reform. By granting certain powers and right to the regions, local authorities and local self-government bodies, we must not forget about the need for a unified state policy, sole authority. It is the citizens who should determine the possibility of making decisions that affect their lives and implement these decisions through the authorities of the community.

Thus, the embodiment of the idea of "new regionalism" is not so much with the state as with the individual regions, which acquire new signs of the European processes and get the right to independent actions. It is important for the united European community to be an establishment of regionalism which does not hinder further European integration.

Among the globalization manifestations an important trend is economic management complications. It requires increasing of the regions role in economic development on the basis of decentralization and new structuring. Mostly it refers to contradictory interaction between local territorial entities, the state and the world economy. Regions compete for the connection to innovative and financial centers, the so-called "gates of the global economy". As a result of such processes, there is a new economic geography that develops economic activity systems taking into account the paradigm of production space in the era of globalization and information society.

Ensuring effective management of spatial development, solving strategic tasks and everyday problems of regional and municipal management largely depends on the level of competence of civil servants and officials of the authorities' local government at the national, regional and local levels. In fact, competence, ability to make thoughtful decisions are the features that will ensure the success of the decentralization process, especially at the basic level [2].

It is also important to pay attention to the structure of the apparatus, especially of rural and settlement amalgamated community. They create quite arbitrarily their own structural units to look after the functioning of social institutions and communal facilities. After all, only sessions of councils form the staff, terms of remuneration, qualification requirements and quite often dissociate themselves with the current standards of appropriate functional subdivisions of district state administrations, their service rights and obligations under applicable law [2].

Regional policy should be conducted so that the forces of the regions to the whole country are strengthened simultaneously. Only under such conditions we can talk about preservation of territorial integrity, uniform development of all regions of the country, increase of living standards and safety of citizens. The main purpose of decentralization is not to create new communities, not to create "transparent offices", municipal police and public firefighters, not to replace the lamps in parks and not to construct tracks for cyclists, but to create the communities of effective subjects of management which will work primarily on creation of new jobs and infrastructure objects [9].

Decentralization is not a permanent process, not an end in itself, but a mechanism for improving the effectiveness and efficiency of public administration and local self-government according to European standards.

In our opinion, the main tasks of the modern management system in Ukraine should become harmonization of the reconstruction and modernization model of institutionalization at the state level and enhancement of the role of communities in the complex and balanced development of all taxonomical units (Fig. 1). 


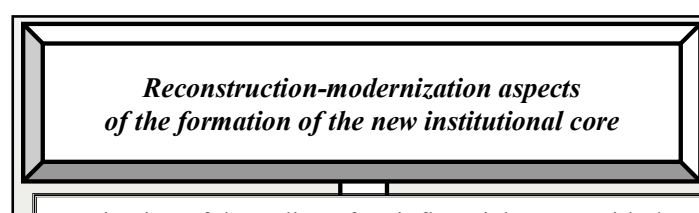

Rejection of the policy of an influential center with the reorientation of the Triad "effective hromadas - balanced regions - a strong state"

Harmonisation of vertical and horizontal power manifestation towards a balanced and comprehensive development of rural and urban areas

Modernization of Spatial Development strategic programming system based on a combination of interests at macro-, meso-and micro-levels

Rejection of the policy of redistribution of resources, espestrategy of territorial development, which would create equal opportunities for realization of their available competitive advantages

Introduction of an axiological model of deconcentration of functions of social comforts and social protection exclusively at their place of residence

Localization of the economic sphere with the levers of supporting the cluster formations, technoparks, technopolises, logistics platforms, industrial parks, production cooperatives and other innovative territorial and production forms of economy optimization

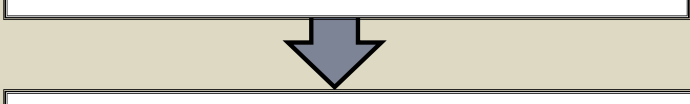

Involvement of local initiatives in solving environmental problems and rational nature management, especially i terms of efficient land use, community resources

of communal form of ownership, small rivers, lakes, who ecosystems, flora and household waste, elimination of natural landfills, etc.
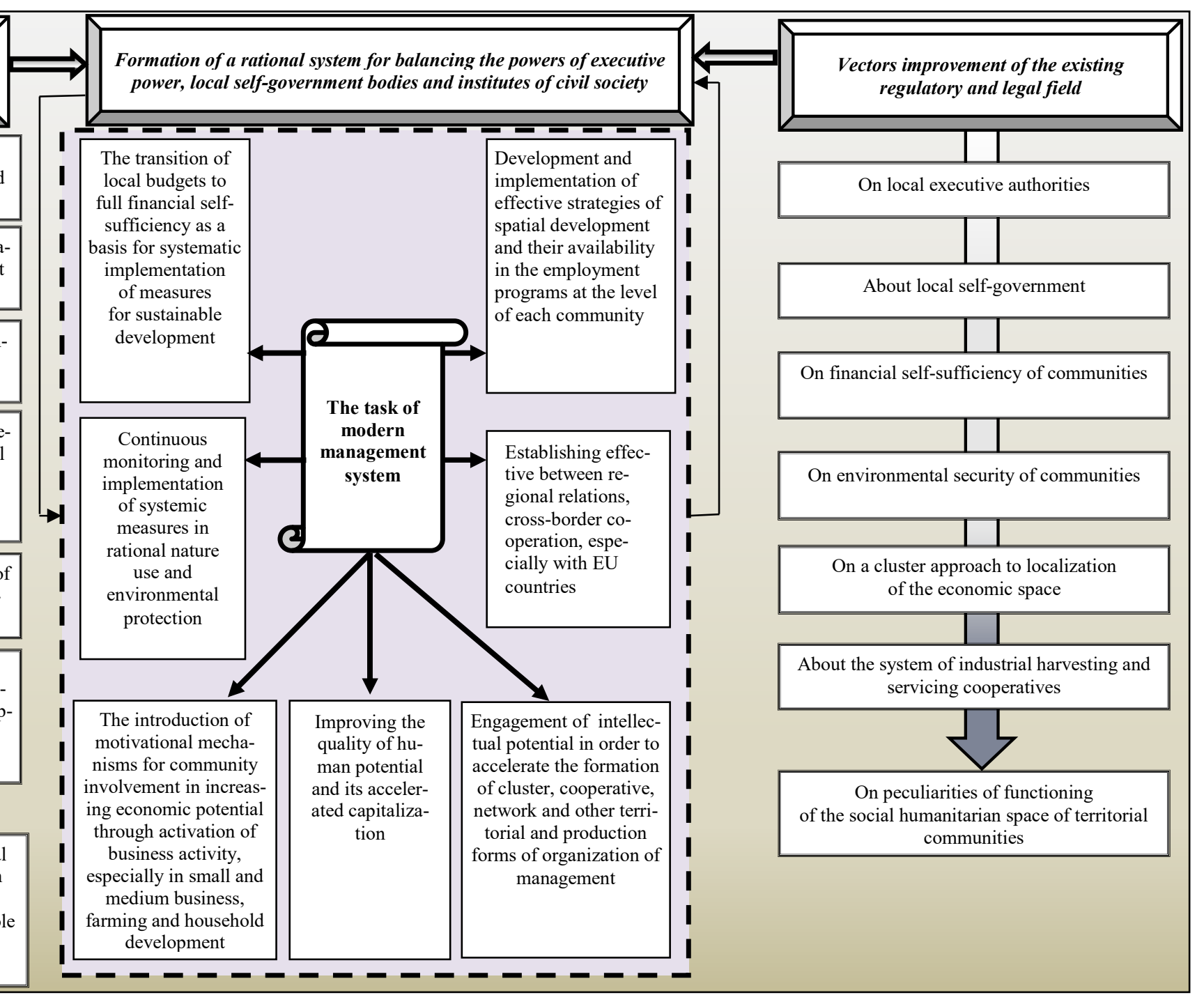

Fig. 1. Reconstructive modernization aspects of the establishment of a new institutional core 
ПРОБЛЕМИ МЕНЕДЖМЕНТУ ТА РОЗВИТКУ ПРОДУКТИВНИХ СИЛ РЕГІОНУ

According to the harmonization of institutional influence on regional development processes we believe that reconciliation of the interests of various formal and informal institutes, as well as organizations, promotes the implementation of the principles of democratic governance and coordinates their compatible activities on the way to achieving the declared regional development goals.

It is necessary to understand the processes of deconcentration which consist in transferring of managerial functions from central to local authorities and decentralization - transferring of rights, duties and separate functions to the level of individual territorial communities and regions.

Conclusions. The reforming of the power of authority in Ukraine should be based on the experience of the developed European countries and the implementation of their decentralization standards to the volatility of national peculiarities that will help to avoid many traps, reduce optimization of the domestic algorithm for reforms.

The mechanism of functioning of the regions of Ukraine in the context of reformatting should be based on the fact that this is part of the national space where full cycles of human resources, the main and working means, national wealth are carried out.

The main condition for realization of the established directions of modernization of the regional power system is to harmonize not only the national and sub-national interests, but also taking into account the sub-regional peculiarities. Regional interests regardless of the level of their awareness is an objectively existing phenomenon. The interests of communities are not only the condition and motivation of economic development, but they are a part of it which causes the entire territorial organization of society.

Modernization should be accompanied by measures for substantial diversification of domestic production, its withdrawal from raw materials and low technological monospecialization, refusal of excessive export orientation, as regards reorientation of moderate protectability in the needs of the domestic market and the reduction of the import dependencies of domestic consumer and investment commodity markets.

\section{References}

1. Butko, M. P. (2016). Arkhitektonika konkurentospromozhnosti rehioniv Ukrainy v konteksti yevrointehratsii [Architectonics of Competitiveness of Ukraine's Regions in the Context of European Integration]. AMU.

2. Butko, M. P. (2017). Bifurkatsiinyi stan derzhavotvorchoho yadra Ukrainy v umovakh realizatsii yevrointehratsiinoho kursu [Bifurcation camp of the core of Ukraine in the minds of the implementation of the European integration course]. Ekonomika Ukrainy - Economy of Ukraine, 10, pp. 49-64.

3. Butko, M. P., Kolosha, V. P., Popelo, O. V. (2019). Osoblyvosti lokalizatsii ekonomichnoho prostoru rehioniv $\mathrm{v}$ umovakh detsentralizatsii vladnykh povnovazhen [Peculiarities of localization of economic space of regions in the conditions of decentralization of power]. Ekonomika Ukrainy Ukraine economy, 1, pp. 60-74.

4. Butko, M., Popelo, O., Revko, A. (2020). Methodology for Assessing the Inflence of Cultural Infrastructure on Regional Development in Poland and Ukraine. Comparatie Economic Research. Central and Eastern Europe, 23 (2), pp. 21-39.

5. Dubnytskyi, V. I., Fedulova, S. O. (2016). Peredumovy transformatsiinykh protsesiv v rehionakh Ukrainy [Background of Transformation Processes in the Regions of Ukraine]. Rehionalna ekonomika - Regional economy, 2 (80), pp. 34-43.

6. Marhasova, V. G., Anishchenko, V. O., Kurmaiev, P. Y. (2018). Ecological component of the society development in the economic theories of reproduction. Scientific Bulletin of Polissya, 1(1(13)), pp. 25-32. http://journals.uran.ua/nvp_chntu/article/view/131016.

7. Padalka O. S., Kulishov V. V. (2015). Detsentralizatsiia - nova paradyhma sotsialnoekonomichnoho rozvytku rehioniv Ukrainy [Decentralization is a new paradigm of socio-economic development of the regions of Ukraine]. Ekonomika Ukrainy - Economy of Ukraine, 10, pp. 45-53.

8. Popelo, O. V. (2018). Lokalizatsiia ekonomichnoho prostoru rehioniv Ukrainy $v$ konteksti yevrointehratsii [Localization of the economic space of Ukraine's regions in the context of European integration]. ChNTU. 
9. Symonenko, V. K. (2017). Reformy: administratyvno-terytorialna, administratyvna i detsentralizatsii - tryiedyni [Reforms: administrative-territorial, administrative and decentralization - triune]. Rehionalna ekonomika - Regional economy, 2, pp. 5-9.

10. Tarasevych, V. M. (2017). Chvert stolittia nezalezhnosti Ukrainy: aktualni konteksty ta imperatyvy sotsialno-ekonomichnykh reform [The quarter of the century of Ukraine's independence: the actual contexts and imperatives of socio-economic reforms]. Ekonomika Ukrainy - Economy of Ukraine, 8, pp. 14-28.

11. Yeshchenko, P. S. (2017). Stahnatsiia ukrainskoi ekonomiky: nezavershenist reform chy produmana polityka? [The stagnation of the Ukrainian economy: incomplete reforms or well-thought out policy?]. Ekonomika Ukrainy - Economy of Ukraine, 8, pp. 29-46.

12. Zahorskyi, V. S. (2016). Derzhavne upravlinnia v systemi formuvannia i realizatsii rehionalnoi polityky $\mathrm{v}$ suchasnykh umovakh [Public administration in the system of formation and implementation of regional policy in modern conditions]. Rehionalna ekonomika - Regional economy, 3 (81), pp. 19-25.

\section{References (in language original)}

1. Бутко М. П. Архітектоніка конкурентоспроможності регіонів України в контексті євроінтеграції : монографія. Київ : АМУ, 2016. 452 с.

2. Бутко М. П. Біфуркаційний стан державотворчого ядра України в умовах реалізації євроінтеграційного курсу. Економіка України. 2017. № 10. С. 49-64.

3. Бутко М. П., Колоша В. П., Попело О. В. Особливості локалізації економічного простору регіонів в умовах децентралізації владних повноважень. Економіка України. 2019. № 1. С. 60-74.

4. Butko M., Popelo O., Revko A. Methodology for Assessing the Inflence of Cultural Infrastructure on Regional Development in Poland and Ukraine. Comparatie Economic Research. Central and Eastern Europe. 2020. Vol. 23, Number 2. P. 21-39.

5. Дубницький В. І., Федулова С. О. Передумови трансформаційних процесів у регіонах України. Регіональна економіка. 2016. № 2. С. 34-43.

6. Marhasova V. G., Anishchenko V. O., Kurmaiev P. Y. Ecological component of the society development in the economic theories of reproduction. Scientific Bulletin of Polissia. 2018. № 1(13). Ч. 1. C. 25-32. URL: http://journals.uran.ua/nvp chntu/article/view/131016.

7. Падалка О. С., Кулішов В. В. Децентралізація - нова парадигма соціально-економічного розвитку регіонів України. Економіка України. 2015. № 10. С. 45-53.

8. Попело О. В. Локалізація економічного простору регіонів України в контексті євроінтеграції: монографія. Чернігів : ЧНТУ, 2018. 372 с.

9. Симоненко В. К. Реформи: адміністративно-територіальна, адміністративна і децентралізації - триєдині. Регіональна економіка. 2017. № 2. С. 5-9.

10. Тарасевич В. М. Чверть століття незалежності України: актуальні контексти та імперативи соціально-економічних реформ. Економіка України. 2017. № 8. С. 14-28.

11. Єщенко П. С. Стагнація української економіки: незавершеність реформ чи продумана політика? Економіка України. 2017. № 8. С. 29-46.

12. Загорський В. С. Державне управління в системі формування і реалізації регіональної політики в сучасних умовах. Регіональна економіка. 2016. № 3. С. 19-25.

Popelo Olha - Doctor of Economics, Associate Professor, Department of Management and Public Administration, Chernihiv National University of Technology (95 Shevchenka Str., 14035 Chernihiv, Ukraine).

Попело Ольга Володимирівна - доктор економічних наук, доцент кафедри менеджменту та державної служби, Чернігівський національний технологічний університет (вул. Шевченка, 95, м. Чернігів, 14035, Україна).

Попело Ольга Владимировна - доктор экономических наук, доцент кафедры менеджмента и государ-

ственной службы, Черниговский национальный технологический университет (ул. Шевченко, 95, г. Чернигов, 14035, Украина).

E-mail: popelo.olha@gmail.com

ORCID: https://orcid.org/0000-0002-4581-5129

ResearcherID: I-8572-2016

Publons ID: AAC-1918-2019

Popelo, O. (2020). Regional economy in the conditions of decentralized governance: institutional aspect. Problems and prospects of economics and management, 2(22), pp. 88-100. 